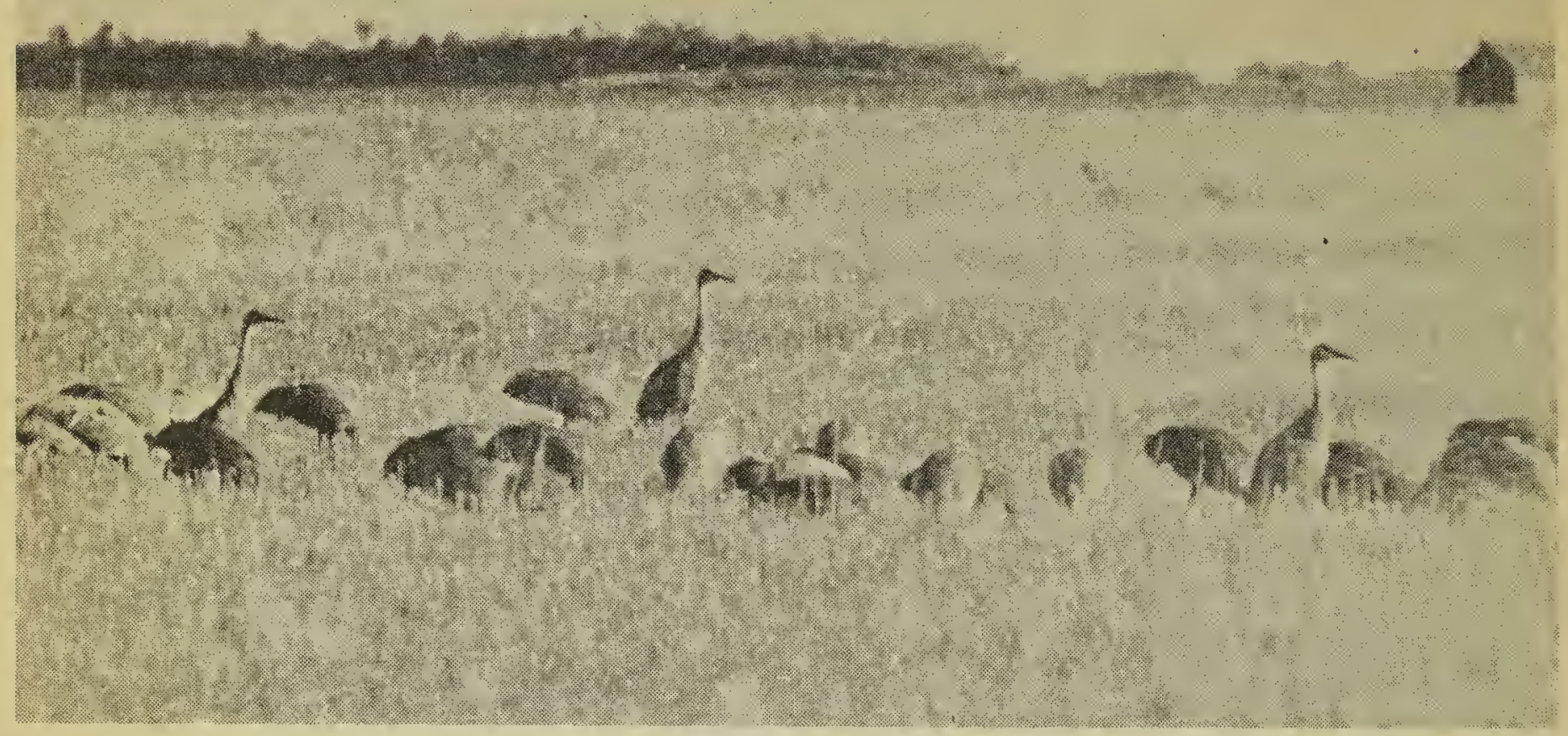

SANDHILLS feeding in the grain fields.

Photo by F. W. Lahrman

Last Mountain Lake area, it was considered necessary by wildlife authorities to permit hunters to assist the farmers in protecting crops where cranes were causing damage. An area in the province was designated wherein individual farmers were not required to obtain a special permit to protect their crops against damage. This was not a new practice; it has been conducted in the past but only when the situation was extremely serious.

Such a policy permitting the shooting of Sandhill Cranes is distasteful to many and this feeling was so expressed in a resolution recently passed at the Moose Jaw meeting of the Saskatchewan Natural History Society. It is commendable that there is an organization of this kind to keep the public aware of what is happening to the wildlife of the province. But at the same time we must be careful to maintain a wide, yet practical viewpoint-one that allows all aspects to be clearly envisaged.

Perhaps there are some ways in which the Sandhill Cranes can be protected from destruction without depriving individuals of their livelihood. If so this is where our energies and resources should be directed. Would refuges or lure crops established in key positions be the answer? Would a program of purchasing entire fields of unharvested grain in serious depredation areas do the trick? New scaring devices or techniques may help. Whatever the answer, if it is to be effective, it will require effort and money!

How much are the Sandhill Cranes worth to you?

\title{
TV Tower Casualty List
}

\section{By F. W. Lahrman, Saskatchewan Museum of Natural History}

On September 22, 1959, I visited the Moose Jaw TV tower which is located approximately four miles south and four miles west of Caron, Sask., to see if any birds had been killed by flying into the tower or guy wires. This 480-foot tower is situated on a height of land at 2400 feet which slopes down approximately 500 feet to the surrounding plain to the north and east. I had noticed a "wave" of warblers and sparrows that morning and since towers are known hazards for migrating birds, decided that the tower might be worth checking.

I found in all 33 birds of 13 species strewn about the ground and soutreast of the tower; while most were found within 50 yards of the base of the tower, some were over 100 yards away. A list of the birds which were found follows:

American Coot (1), Red-eyed 


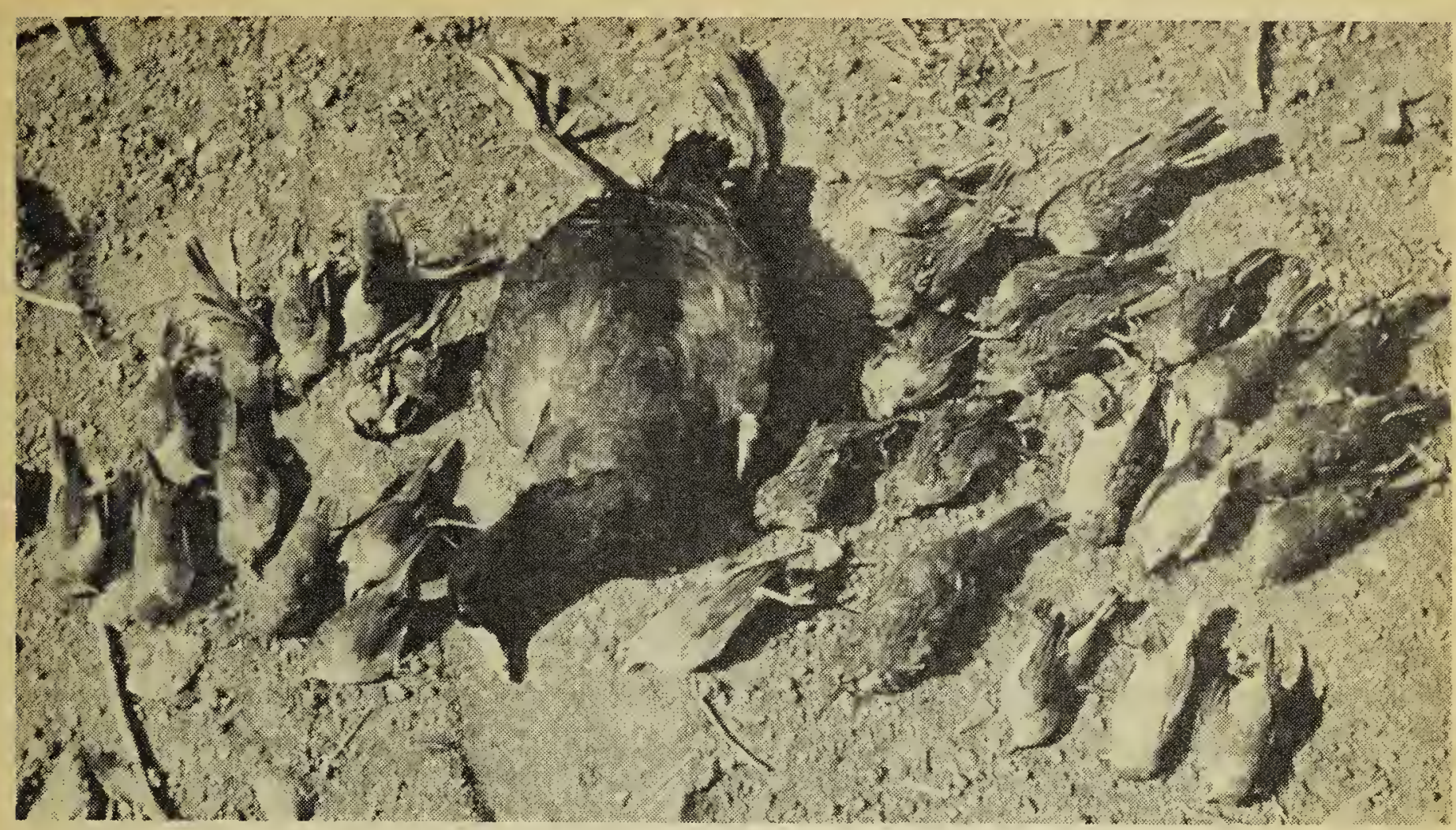

Photo by F. W. Lahrman

Birds collected at Moose Jaw T.V. tower, Sept. 22, 1959.

Vireo (1), Black-and-White Warbler (1), Orange-crowned Warbler (6), Yellow Warbler (3), Palm Warbler (3), Myrtle Warbler (7), Yellowthroat (2), Savannah Sparrow (1), Sharp-tailed Sparrow (1), Vesper Sparrow (1), Fox Sparrow (1), Lincoln (5).

All of the abcve birds appeared to be quite freshly killed - doubtless mostly within the past 48 rours. A number of other birds found which had evidently been killed at an earlier date were: Gadwall (1), Bluewinged Teal (1), Red-eyed Vireo (1), Myrtle Warbler (several), White-throated Sparrow (1). In addition three Myrtles, one Yellowthroat, and one Orange-crowned Warbler were found injured but able to flutter away. The past two previous nights when this cccurred were overcast and misty. On September 23, I visited the tower again and found one Red Bat (Lasiurus borealis) and one injured Least Flycatcher.

In this connection, it is interesting to note the conclusions drawn by William W. Cochran and Richard R. Graber, in an article "Attraction of nocturnal migrants by light on a television tower" (Wilson Bulletin, $70: 378-380,1958)$. They find that (1) "Migrants are attracted to the towers by the tower lights, and (2) only a very small per cent of the birds which reach the tower are killed" and that their observations indicate "that confusion of nocturnal migrants by tower lights occurs only on nights when the ceiling is low, and migrants are apparently forced to fly near or below the 1000 to 3000 feet level.",

If we accept this conclusion, a higher tower would present greater danger to migrants. C. A. Kemper (1958. Destruction at the TV Tower, Passenger Pigeon, 20:3-9) noted this, reporting that a 500-foot tower in Wisconsin checked regularly showed little kill but when a second tower cf 1000 feet was placed nearby there was an immediate drastic increase in mortality. Kemper gave these figures for three major collisions at the two towers: on Aug. 29, 1957, up to 500 birds were killed; on Sept. 3, up to 400; and on Sept. 20-and tris is no typographical error!-a conservative estimate of 20,000 birds covered the ground for up to three-quarters of a mile away.

There have been few reports of TV tower bird casualties in the Great Plains, and the Moose Jaw report is probably the largest for the Northern Plains. It is therefore important to get all the information we can about these tragedies-the circumstances under which they occur, meteorological data, species involved, and any unusual behaviour observed at the site. 